\title{
PERAN TELAGA DALAM PEMENUHAN KEBUTUHAN AIR KAWASAN KARST GUNUNGSEWU PASCA PEMBANGUNAN JARINGAN AIR BERSIH
}

\author{
Oleh: \\ Ahmad Cahyadi \\ Departemen Geografi Lingkungan Fakultas Geografi Universitas Gadjah Mada Yogyakarta \\ Kelompok Studi Karst Fakultas Geografi universitas Gadjah Mada \\ ahmadcahyadi@geo.ugm.ac.id
}

\begin{abstract}
Abstrak
Kawasan karst adalah kawasan yang terbentuk oleh proses pelarutan batuan karbonat sehingga menyebabkan kondisi kering di permukaan dan kaya air di bawah permukaan. Hal tersebut menyebabkan sumber air permukaan yang langka seperti telaga dan mataair menjadi sangat penting. Namun demikian, saat ini kawasan karst yang terdapat di Kabupaten Gunungkidul hampir semua telah terjangkau jaringan pipa air bersih. Hal ini tentunya akan menyebabkan ketergantungan terhadap telaga dan mataair menjadi berkurang. Tujuan dari penelitian ini adalah untuk mengetahui peranan telaga dalam pemenuhan kebutuhan air bersih di kawasan karst Kecamatan Semanu Kabupaten Gunungkidul pasca pembangunan jaringan pipa air bersih. Metode yang dilakukan adalah dengan melakukan wawancara mendalam (In-depth interviews) pada 30 blok permukiman yang terletak di kecamatan Semanu. Hasil penelitian menunjukkan bahwa saat ini telaga tidak lagi berfungsi untuk sumber pemenuhan air minum. Namun demikian telaga masih digunakan untuk mencuci, memandikan ternak, sumber air minum untuk ternak, serta tempat budidaya ikan yang dikelola oleh masyarakat secara bersama-sama.
\end{abstract}

Kata kunci: karst, telaga, kebutuhan air

\begin{abstract}
Karst region is a region which is formed by the dissolution of carbonate rocks, causing dry conditions in surface and abundant subsurface water. This causes a rare source of surface water such as logva and springs in which they are very important. However, almost all of karst regions in Gunungkidul Regency have affordable water supply network recently. This will naturally reduce the dependence on the lake and the springs. The objective of this study is to determine the role of logva in the fulfilment of water needs in Gunungsewu karst area, Semanu sub District, Gunungkidul Regency in the postdevelopment of water supply network. The research methods include conducting in-depth interviews in 30 residential blocks located in the Semanu sub District. The results show that the current logva is no longer working for the fulfillment of drinking water sources. However, the logva is still used for washing, bathing the cattle, serving as the source of drinking water for livestock, as well as for farming fish which are jointly managed by the community.
\end{abstract}

Keywords: karst, logva, water needs 


\section{PENDAHULUAN}

Milanovic (2004) menyebutkan bahwa karst adalah bentuklahan yang dominan terbentuk oleh pekarutan batuan gamping, dolomit, marmer, gipsum, dan batuan garam. Kawasan ini diperkirakan menutup kurang lebih 25\% dari permukaan bumi (Milanovic, 2004) dan 20\% dari wilayah Negara Kesatuan Republik Indonesia (Balasz, 1968). Proses pelarutan yang terjadi menyebabkan air permukaan dengan cepat meresap menuju sistem air bawah tanah akibat keberadaan diaklas-diaklas (retakan-retakan) serta lubang-lubang yang berukuran kecil/diffuse, sedang/fissure atau berukuran besar/conduit (White, 1988). Hal ini menyebabkan kondisi di permukaan tanah terkesan gersang berbatu serta banyak air di bawah permukaan (Cahyadi, 2010). Langkanya air permukaan menyebabkan sumber air dipermukaan berupa danau doline/telaga (logva) serta mata air di kawasan karst menjadi sangat penting untuk memenuhi kebutuhan air penduduk (Santosa, 2007).

Kawasan karst Gunungsewu adalah salah satu kawasan karst di Indonesia yang terkenal karea telah ditetapkan sebagai world natural heritage pada Tahun 2006. Kawasan ini memiliki karakteristik khusus berupa bukit karst yang menyerupai bentuk separuh batok kelapa/ kegelkarst (Tjia, 2013), sehingga penemuan bukit dengan bentuk tersebut di manapun kemudian akan disebut karst tipe Gunungsewu. Kawasan karst Gunungsewu tersusun atas batuan gamping berumur Neogen (Miosen Tengah sampai dengan Pleiosen Atas) (Haryono dan Day, 2005). Secara spasial, wilayah utara kawasan karst ini tersusun atas batuan gamping berlapis yang relatif lunak dan pada bagian selatan didominasi oleh batu gamping terumbu yang relatif lebih keras (Surono dkk., 1992; Rahadjo dkk., 1995). Sebagian kawasan ini masuk ke dalam wilayah administrasi Kabupaten Gunungkidul, yang meliputi Kecamatan Ponjong, Wonosari, Rongkop, Girisubo, Tepus, Tanjungsari, Semanu, Panggang, Paliyan, Playen dan Purwosari.

Haryono dkk (2009) menyebutkan bahwa sebelum tahun 1990-an 90\% dari kebutuhan air di kawasan karst Kabupaten Gunungkidul dipenuhi dari telaga karst. Meskipun demikian, saat ini hampir semua permukiman di kawasan karst di Kabupaten Gunungkidul telah dijangkau oleh jaringan pipa PDAM yang memanfaatkan sumber air dari sungai bawah tanah (Suryono, 2006). Kondisi ini tentunya akan menyebabkan perubahan tingkat ketergantungan masyarakat terhadap sumber air yang lain seperti telaga dan mata air di kawasan karst. Oleh karena itu, penelitian ini bertujuan untuk mengetahui peran telaga di Kawasan Karst Gununsewu dalam pemenuhan kebutuhan air pasca pembangunan jaringan air bersih oleh pemerintah. Namun demikian karena keterbatasan waktu dan biaya, maka penelitian ini hanya mengambil studi kasus di kawasan karst yang terletak di Kecamatan Semanu Kabupaten Gunungkidul (Gambar 1). Hal ini karena tiga dari lima sumber air yang digunakan untuk sumber air PDAM terletak di Kecamatan Semanu, sehingga kemungkinan dengan jarak yang dekat ini seluruh wilayah dari kecamatan ini telah terakses jaringan pipa PDAM. 


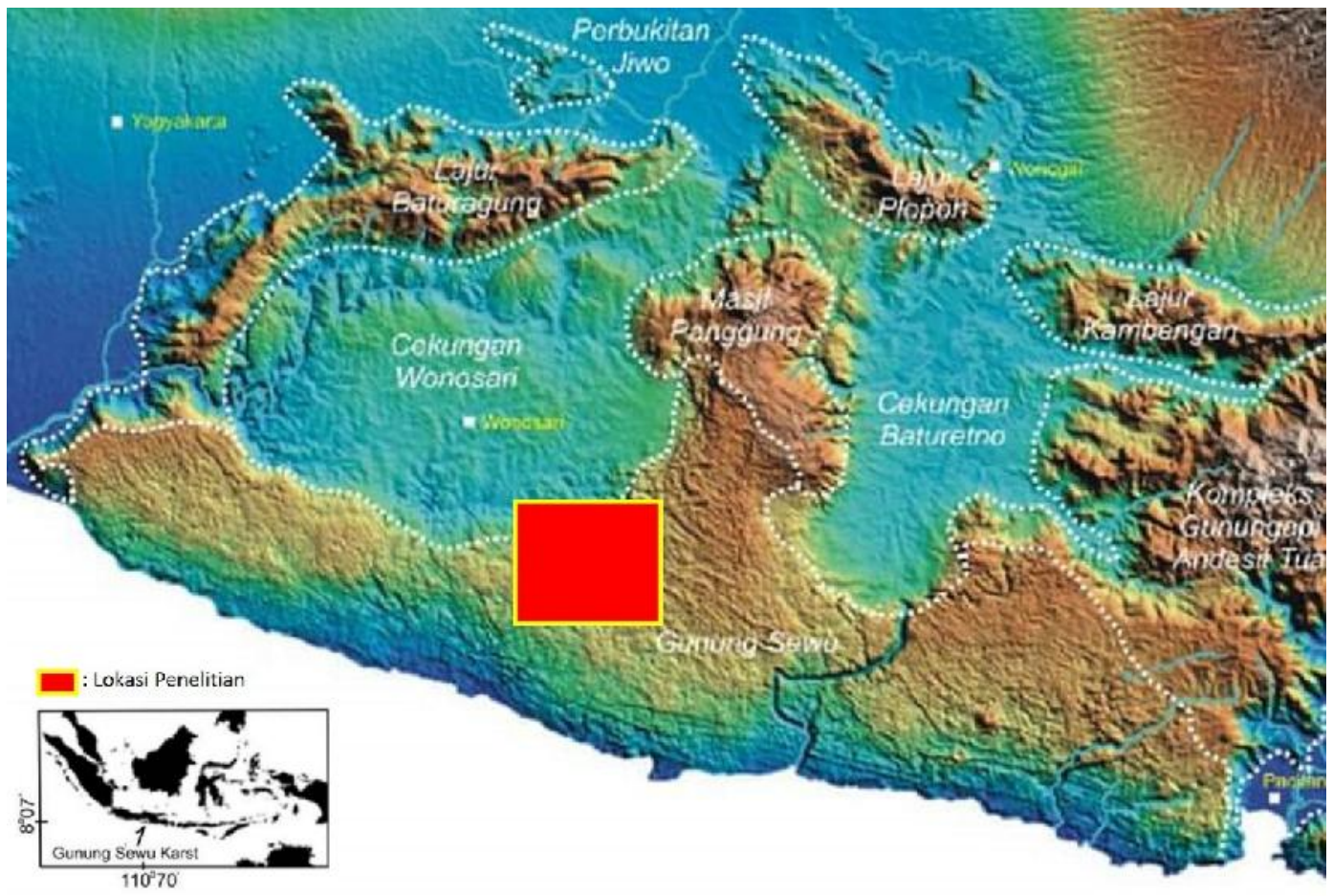

Gambar 1. Lokasi Penelitian di Kawasan Karst Gunungsewu

\section{METODE}

Metode yang digunakan dalam penelitian ini adalah dengan wawancara mendalam (in-depth interviews) pada setiap blok permukiman yang didasarkan pada peta penggunaan lahan yang diekstrak dari peta Rupa Bumi Indonesia (RBI) skala 1: 25.000 terbitan Badan Koordinasi Survei dan Pemetaan Nasional (BAKOSURTANAL). Hal ini didasari kenyataan bahwa pola permukiman yang terdapat di kawasan karst adalah mengelompok (Marfai, 2011). Jumlah blok permukiman yang terdapat di wilayah kajian adalah 30 , sehingga jumlah responden yang digunakan dalam penelitian ini berjumlah 30 orang. Selain itu, kegiatan ini akan melakukan perbaharuan data pemanfaatan telaga yang pada tahun 2007 telah dilakukan penelitian serupa oleh Badan Perencanaan Pembangunan Daerah (Bappeda) Kabupaten Gunungkidul.

\section{HASIL DAN PEMBAHASAN}

Sumber air bersih yang didistribusikan oleh PDAM Kabupaten Gunungkidul bersumber dari lima sumber utama. Kelima sumber air yang digunakan adalah Bribin 1, Bribin 2 (Sindon), Seropan, Baron dan Ngobaran. Keseleruhan sumber air yang digunakan berasal dari aliran sungai bawah tanah. Hasil wawancara mendalam di lokasi penelitian menunjukkan bahwa lokasi penelitian termasuk dalam jaringan air bersih yang berasal dari Bribin 1 dan 2 serta Seropan. Hal yang sama dikemukakan pula oleh Suryono (2006) seperti ditampilkan pada Tabel 1. Terbatasnya jumlah aliran air yang mampu didistribusikan menyebabkan aliran air dari PDAM dilakukan secara bergilir, di mana wilayah yang sama akan teraliri dua hari dalam seminggu. Kondisi ini menyebabkan masyarakat sebanyak 
mungkin mengalirkan air dari PDAM pada saat air PDAM mengalir sampai tampungan air berupa penampungan air hujan $(\mathrm{PAH})$ penuh.

Tabel 1. Sistem Pelayanan Air Bersih PDAM Gunungkidul

\begin{tabular}{|c|c|c|c|c|}
\hline Sistem & Daerah Pelayanan & $\begin{array}{c}\text { Jumlah } \\
\text { Sambungan } \\
\text { Hidran Umum }\end{array}$ & $\begin{array}{c}\text { Jumlah } \\
\text { Sambungan } \\
\text { Saluran Rumah } \\
\text { Tangga }\end{array}$ & $\begin{array}{c}\text { Jumlah } \\
\text { Dusun dan } \\
\text { Desa Yang } \\
\text { Terlayani }\end{array}$ \\
\hline Bribin 1 dan 2 & $\begin{array}{l}\text { Kecamatan Semanu, } \\
\text { Tepus, Rongkop, dan } \\
\text { Girisubo }\end{array}$ & 510 & 7.387 & $\begin{array}{l}134 \text { dusun; } \\
21 \text { desa }\end{array}$ \\
\hline Seropan & $\begin{array}{l}\text { Kecamatan Semanu, } \\
\text { Ponjong, Karangmojo, } \\
\text { dan Wonosari }\end{array}$ & 115 & 7.292 & $\begin{array}{l}134 \text { dusun; } \\
21 \text { desa }\end{array}$ \\
\hline Baron & Kecamatan Tanjungsari & 57 & 874 & $\begin{array}{l}32 \text { dusun; } \\
4 \text { desa }\end{array}$ \\
\hline Ngobaran & $\begin{array}{l}\text { Kecamatan Saptosari, } \\
\text { Purwosari dan } \\
\text { Panggang }\end{array}$ & 180 & 6.811 & $\begin{array}{l}152 \text { dusun; } \\
40 \text { desa }\end{array}$ \\
\hline
\end{tabular}

Sumber: Suryono (2006)

Secara keseluruhan, jumlah telaga karst di Kabupaten Gunungkidul adalah sejumlah 281 (Bappeda Kabupaten Gunungkidul, 2007). Secara spasial, telaga terdapat di 10 dari 18 kecamatan di Kabupaten Gunungkidul. Hal ini karena kawasan karst di Kabupaten Gunungkidul hanya terdapat di bagian selatan. Bagian tengah kabupaten gunungkidul berupa Cekungan Wonosari yang relatif landai dan pada bagian utara didominasi oleh batuan gunugapi purba yang mengalami proses structural membentuk Pegunungan Baturagung. Detail jumlah telaga di masing-masing kecamatan di Kabupaten Gunungkidul ditunjukkan oleh Tabel 2, sedangkan sebaran secara spasial ditunjukkan oleh Gambar 2.

Tabel 2. Jumlah dan Volume Telaga di Kabupaten Gunungkidul

\begin{tabular}{|c|l|c|c|c|}
\hline \multirow{2}{*}{ No. } & \multirow{2}{*}{ Kecamatan } & \multirow{2}{*}{\begin{tabular}{c}
\multirow{2}{*}{ Tumlah } \\
Telaga
\end{tabular}} & \multicolumn{2}{|c|}{ Volume Telaga $\left(\mathbf{m}^{\mathbf{3}} /\right.$ th) } \\
\cline { 4 - 5 } & & 10 & $0-192.000$ & $8.400-288.000$ \\
\hline 1. & Paliyan & 21 & $0-900.000$ & $1.875-1.125 .000$ \\
\hline 2. & Saptosari & 31 & $0-4.500$ & $40-12.000$ \\
\hline 3. & Purwosari & 22 & $0-3.000$ & $7,2-15.000$ \\
\hline 4. & Panggang & 32 & $0-4.500$ & $375-72.000$ \\
\hline 5. & Tepus & 27 & $0-10.000$ & $48-32.400$ \\
\hline 6. & Tanjungsari & 42 & $0-168.750$ & $675-210.000$ \\
\hline 7. & Semanu & 21 & $0-600.000$ & $1.000-1.200 .000$ \\
\hline 8. & Ponjong & 48 & $0-16.800$ & $600-$ \\
\hline 9. & Rongkop & 27 & $0-13.500$ & $675-600$ \\
\hline 10. & Girisubo & 40.000 \\
\hline
\end{tabular}

Sumber: Bappeda Kabupaten Gunungkidul (2007) 


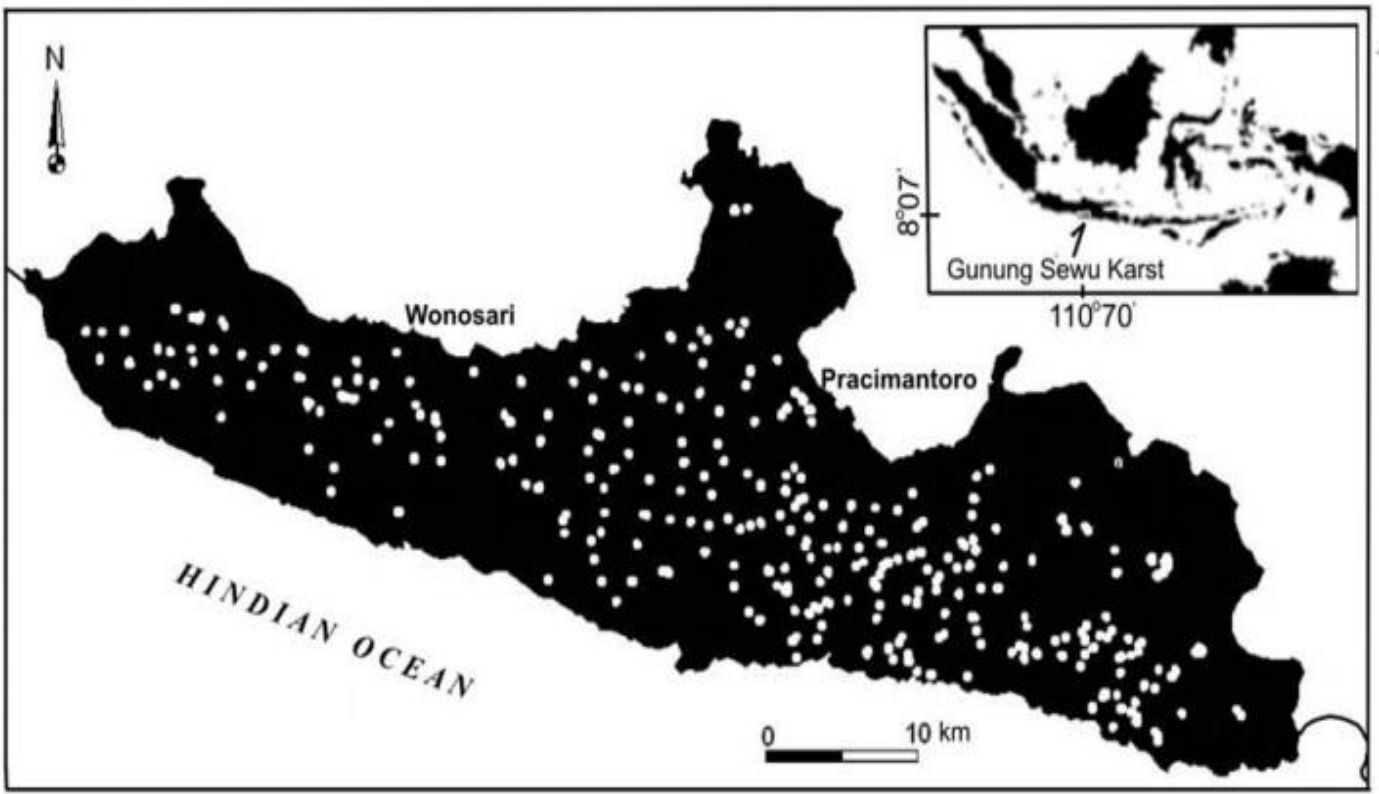

Gambar 2. Sebaran Telaga di Kabupaten Gunungkidul (Haryono dkk., 2009)

Jumlah telaga di Kecamatan Semanu cukup banyak, tercatat ada 42 telaga yang tersebar di semua desa yang terdapat di Kecamatan Semanu. Hasil pengatan dan wawancara menunjukkan bahwa hampir semua telaga mengalami kondisi kering ketika musim kemarau. Hanya terdapat 5 telaga yang tidak mengalami kekeringan pada saat musim kemarau yaitu Telaga Bogosari di Desa Candirejo, Telaga Jonge, Telaga Ledok dan Telaga Lebuh di Desa Pacarejo, Telaga Mijahan di Desa Semanu.

Hasil wawancara mendalam menunjukkan bahwa pada masa lalu ketika jaringan air bersih belum ada, masyarakat menggunakan telaga untuk memenuhi kebutuhan air minum, memasak, mencuci, memandikan ternak serta untuk sumber air bagi ternak. Hal ini dilaporkan juga oleh Worosuprojo (1997) dan Santosa (2007) yang menyebutkan bahwa telaga memiliki peranan yang sangat penting dalam pemenuhan kebutuhan air di kawasan karst Kabupaten gunungkidul, khususnya pada saat musim kemarau. Kondisi ini disebabkan karena kebutuhan air pada musim dipenuhi dari air hujan, di mana pada musim kemarau curah hujan yang jatuh sangat sedikit atau bahkan tidak ada. Pemanenan air hujan umumnya dilakukan dengan mengalirkan air hujan yang jatuh pada atap rumah ke tempat penampungan air hujan (PAH).

Hasil analisis menunjukkan saat ini telaga di Kecamatan Semanu tidak ada lagi yang digunakan sebagai sumber air minum (Tabel 3), padahal kajian Bappeda Kabupaten Gunungkidul tahun 2007 menyatakan masih terdapat 6 telaga yang digunakan untuk sumber air minum. Meskipun demikian, masyarakat di kawasan karst Kecamatan Semanu menganggap keberadaan telaga masih menjadi bagian penting dalam pemenuhan kebutuhan air. Hal ini karena saat ini telaga masih digunakan untuk mencuci, memandikan ternak, sumber air minum untuk ternak, serta tempat budidaya ikan yang dikelola oleh 
masyarakat secara bersama-sama (Gambar 3). Selain itu, persepsi tentang telaga sebagai bagian penting dalam pemenuhan kebutuhan air di kawasan karst dapat dilihat dari perilaku masyarakat dalam menjaga kondisi telaga seperti adanya larangan menebang pohon di sekitar telaga dan penghijauan wilayah di sekitar telaga. Namun demikian, kondisi beberapa telaga yang telah mati dan tidak lagi tergenang air (hanya tergenang dalam waktu sangat singkat setelah hujan atau bahkan menjadi tegalan) akibat pendangkalan menyebabkan masyarakat menjadikannya tanah kas dusun yang di sewakan untuk kegiatan pertanian. Setiap awal tahun tanam, dilakukan lelang bagi masyarakat yang berminat untuk mengolah tanah bekas telaga. Pemenang lelang dapat mengolah lahan bekas telaga selama satu tahun. Kondisi ini terjadi misalnya di telaga Ploso, Dusun Ploso, Desa Dadapayu.

Tabel 3. Pemanfaatan Telaga di Kecamatan Semanu

\begin{tabular}{|r|l|l|l|r|l|}
\hline No & Nama Telaga & Dusun/Dukuh & \multicolumn{1}{|c|}{ Desa } & $\begin{array}{r}\text { Volume } \\
\text { Rerata }\left(\mathrm{m}^{3}\right)\end{array}$ & Pemanfaatan Air \\
\hline 1 & Mijahan & Mijahan & Semanu & 4.500 & $\begin{array}{l}\text { Mandi, mencuci, } \\
\text { ternak, perikanan }\end{array}$ \\
\hline 2 & Pragak & Pragak & Semanu & 12.000 & $\begin{array}{l}\text { Mandi, mencuci, } \\
\text { ternak, perikanan, } \\
\text { pertanian }\end{array}$ \\
\hline 3 & Pragak & Pragak & Semanu & 225 & pertanian \\
\hline 4 & Tambak & Tambakrejo & Semanu & 78.750 & $\begin{array}{l}\text { Mandi, mencuci, } \\
\text { ternak, pertanian }\end{array}$ \\
\hline 5 & Clorot & Clorot & Semanu & 0 & Tidak ada \\
\hline 6 & Jemblong & Pucangsari & Candirejo & 0 & Tidak ada \\
\hline 7 & Ceblok & Pucangsari & Candirejo & 3.000 & $\begin{array}{l}\text { Mandi, mencuci, } \\
\text { ternak }\end{array}$ \\
\hline 8 & Nangsri & Nangsri Lor & Candirejo & 18.000 & $\begin{array}{l}\text { Mandi, mencuci, } \\
\text { ternak, perikanan }\end{array}$ \\
\hline 9 & Kedukan & Plebengan & Candirejo & 2.730 & $\begin{array}{l}\text { Mandi, mencuci, } \\
\text { ternak, perikanan }\end{array}$ \\
\hline 10 & Bowongan & Panggul & Candirejo & 900 & $\begin{array}{l}\text { Mandi, mencuci, } \\
\text { ternak, perikanan }\end{array}$ \\
\hline 11 & Bogosari & Gunung Kulir & Candirejo & 13.000 & $\begin{array}{l}\text { Mandi, mencuci, } \\
\text { ternak, perikanan }\end{array}$ \\
\hline 12 & Lemahmendak & Kropak & Candirejo & 1.800 & $\begin{array}{l}\text { Mandi, mencuci, } \\
\text { ternak, perikanan, } \\
\text { pertanian }\end{array}$ \\
\hline 13 & Srilulut 1 & Serpeng & Pacarejo & 168.750 & $\begin{array}{l}\text { Mandi, mencuci, } \\
\text { ternak, perikanan }\end{array}$ \\
\hline 14 & Srilulut 2 & Serpeng & Pacarejo & 60.000 & $\begin{array}{l}\text { Mandi, mencuci, } \\
\text { ternak, perikanan }\end{array}$ \\
\hline 15 & Pacing & Pacing & Pacarejo & 3.750 & $\begin{array}{l}\text { Mandi, mencuci, } \\
\text { ternak, perikanan }\end{array}$ \\
\hline 16 & Dengok & Dengok & Pacarejo & 22.500 & $\begin{array}{l}\text { Mandi, mencuci, } \\
\text { ternak, perikanan }\end{array}$ \\
\hline
\end{tabular}




\begin{tabular}{|c|c|c|c|c|c|}
\hline 17 & Mendak & Dengokngampu & Pacarejo & 800 & $\begin{array}{l}\text { Mandi, mencuci, } \\
\text { ternak, perikanan }\end{array}$ \\
\hline 18 & Ginaru & Dengok & Pacarejo & 0 & Tidak ada \\
\hline 19 & Sureng & Jasem & Pacarejo & 12.500 & $\begin{array}{l}\text { Mandi, mencuci, } \\
\text { ternak, perikanan }\end{array}$ \\
\hline 20 & Ledok & Kuwon & Pacarejo & 19.800 & $\begin{array}{l}\text { Mandi, mencuci, } \\
\text { ternak, perikanan }\end{array}$ \\
\hline 21 & Lebuh & Kuwon & Pacarejo & 480 & $\begin{array}{l}\text { Mandi, mencuci, } \\
\text { ternak, perikanan, } \\
\text { pertanian }\end{array}$ \\
\hline 22 & Tanjung & Kwangen & Pacarejo & 15.750 & $\begin{array}{l}\text { Mandi, mencuci, } \\
\text { ternak, perikanan, } \\
\text { Pertanian }\end{array}$ \\
\hline 23 & Jonge & Jonge & Pacarejo & 36.000 & $\begin{array}{l}\text { Mandi, mencuci, } \\
\text { ternak, perikanan, } \\
\text { perikanan }\end{array}$ \\
\hline 24 & Jetis & Jetis & Pacarejo & 9.600 & $\begin{array}{l}\text { Mandi, mencuci, } \\
\text { ternak, perikanan, } \\
\text { pertanian }\end{array}$ \\
\hline 25 & Gandu & Piyuyon & Pacarejo & 7.425 & $\begin{array}{l}\text { Mandi, mencuci, } \\
\text { ternak, perikanan }\end{array}$ \\
\hline 26 & Krecek & Banyumanik & Pacarejo & 200 & $\begin{array}{l}\text { Mandi, mencuci, } \\
\text { ternak, perikanan }\end{array}$ \\
\hline 27 & Jambe & Dayakan & Dadapayu & 0 & Ternak \\
\hline 28 & Tirisan & Kerdon & Dadapayu & 187.5 & $\begin{array}{l}\text { Mandi, cuci, } \\
\text { ternak, perikanan }\end{array}$ \\
\hline 29 & Sempon & Sempon & Dadapayu & 588 & $\begin{array}{l}\text { Mandi, mencuci, } \\
\text { ternak, perikanan }\end{array}$ \\
\hline 30 & Badut & Dedel & Dadapayu & 200 & $\begin{array}{l}\text { Mandi, mencuci, } \\
\text { ternak, perikanan }\end{array}$ \\
\hline 31 & Petit & Dedel & Dadapayu & 0 & Ternak, perikanan \\
\hline 32 & Belik & Pomahan & Dadapayu & 5.200 & Ternak, perikanan \\
\hline 33 & Widoro & Karang Tengah & Dadapayu & 1.575 & $\begin{array}{l}\text { Mandi, mencuci, } \\
\text { ternak, perikanan }\end{array}$ \\
\hline 34 & Sentul & Ploso & Dadapayu & 0 & Tidak ada \\
\hline 35 & Ngepung & Nongkosingit & Dadapayu & 0 & Tidak ada \\
\hline 36 & Wuluh & Nongkosingit & Dadapayu & 0 & Tidak ada \\
\hline 37 & Bolang & Pacar & Dadapayu & 960 & Mandi, mencuci \\
\hline 38 & Sangu Pati & Jragum & Ngeposari & 0 & Tidak ada \\
\hline 39 & Gesing & Jragum & Ngeposari & 0 & Tidak ada \\
\hline 40 & Pego & Jragum & Ngeposari & 0 & Tidak ada \\
\hline 41 & Peden & Wediutah & Ngeposari & 13.125 & Ternak \\
\hline 42 & Tlempek & Sumuluh Lor & Ngeposari & 0 & Tidak ada \\
\hline
\end{tabular}

Sumber: Perbaruan Data Bappeda (2007) dan Analisis Data Hasil Penelitian 


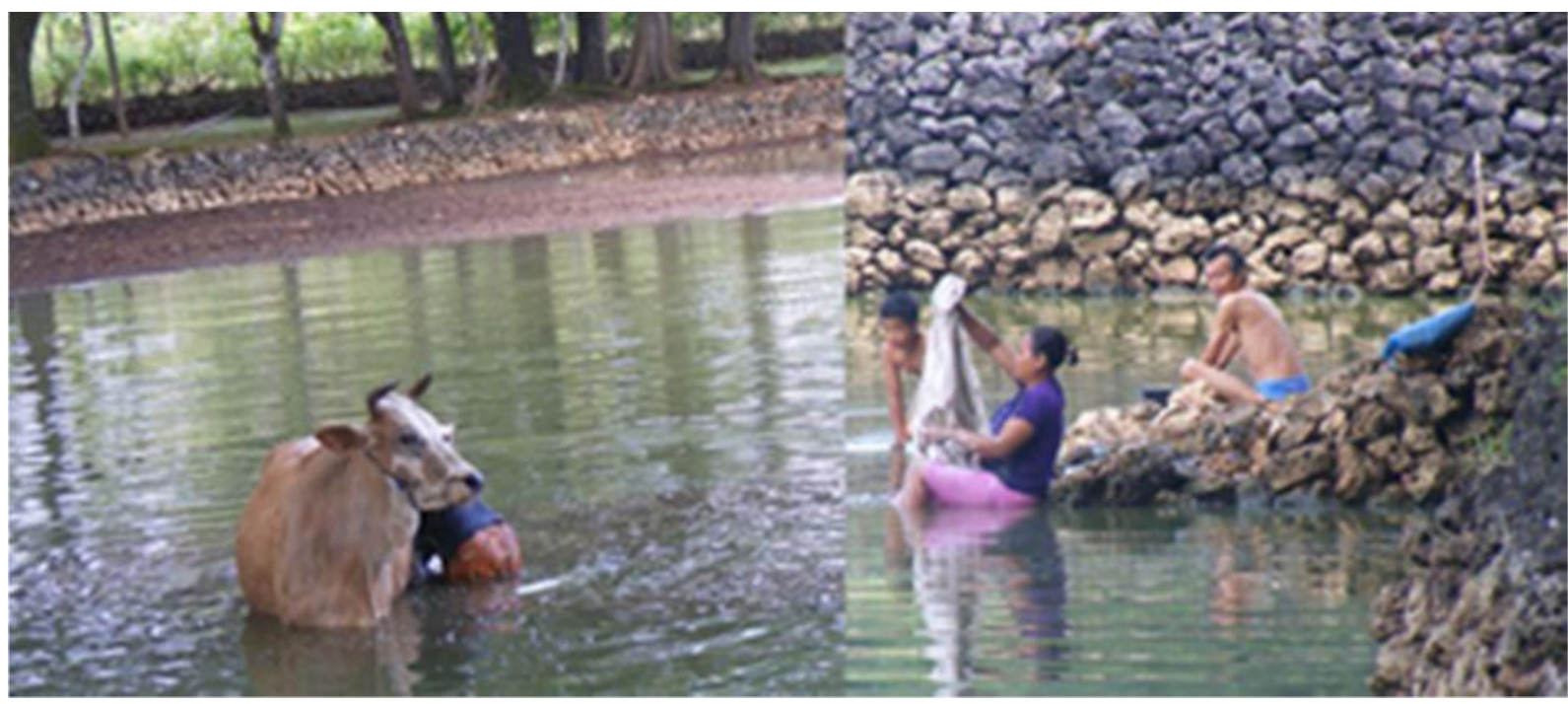

Gambar 3. Pemanfaatan Telaga Nangsri untuk Memandikan ternak, Mencuci dan Mandi

Hasil wawancara mendalam mengungkap fakta bahwa banyak telaga di kawasan karst Kecamatan Semanu telah mengalami kerusakan. Kerusakan terjadi akibat pendangkalan dan terbukanya sistem saluran bawah tanah akibat pengerukan saat dilakukan pembangunan talut. Telaga Pego yang terletak di Dusun Gemulung, Desa Ngeposari misalnya, mengalami pendangkalan yang hebat sejak dilakukannya penebangan kayu secara ilegal dan pengolahan tegalan pada perbukitan di sekitarnya. Kondisi ini mulai terjadi pada Tahun 1980-an. Selain itu, beberapa responsden menggungkapkan bahwa banyak telaga yang menjadi kering pada saat musim kemarau sejak dilakukan pembangunan talut oleh pemerintah (beberapa menyebutkan dilakukan melalui program ABRI masuk desa) yang banyak terjadi pada Tahun 1980-an sampai awal 1990-an. Kondisi ini misalnya terjadi di Telaga Bulu, Dusun Bulu serta Telaga Plebengan di Dusun Plebengan, Desa Candirejo (Gambar 4). Hal ini terjadi akibat proses pembangunan yang dilakukan dengan pengerukan tanah di dalam telaga telah membuka saluran atau lubang yang menghubungkan dengan sistem sungai bawah tanah. Lubang tersebut awalnya tertutup oleh sedimen lempung yang tidak tembus air (impermeable), namun karena pengerukan makan lubang atau lorong tersebut terbuka di bagian bawah atau samaping telaga. Kondisi tersebut menyebabkan kapasitas telaga berkurang serta resapan ke dalam sistem sungai bawah tanah menjadi lebih banyak sehingga pada musim kemarau telaga menjadi kering. 


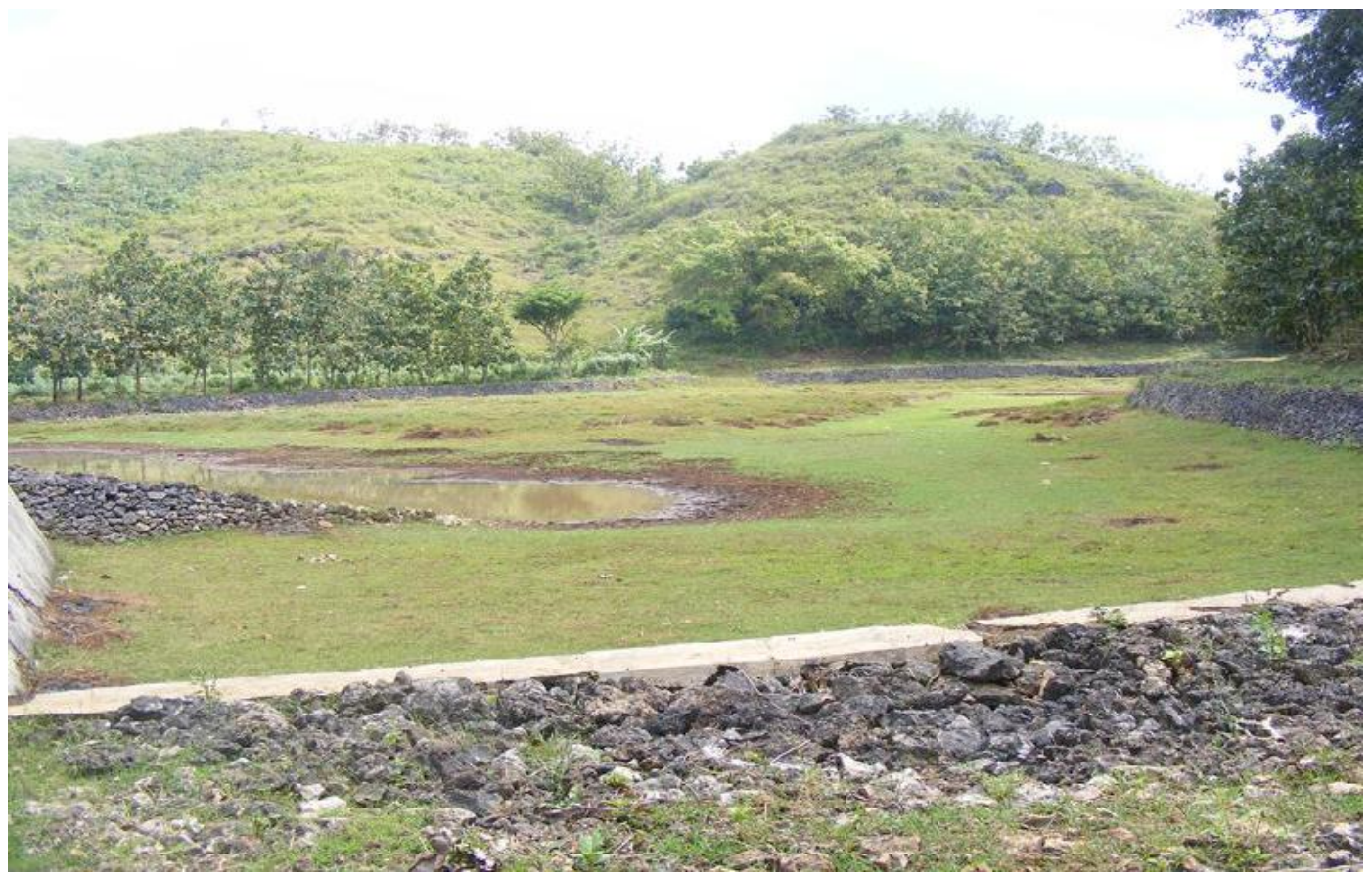

Gambar 4. Telaga Plebengan Lor yang Selalu Kering saat Musim Kemarau Pasca di Talud

Haryono dkk. (2009) menyebutkan bahwa umumnya telaga di kawasan karst Gunungsewu memiliki 3 masalah lingkungan utama, yaitu berkurangnya kapasitas simpanan air, kehilangan air yang cepat dan semakin menurunnya kualitas air. Kondisi tersebut semuanya terjadi di telaga-telaga di Kecamatan Semanu. Berkurangnya kapasitas tampungan disebabkan karena berkurangnya volume telaga yang disebabkan oleh sedimentasi material yang berasal dari daerah tangkapan air telaga. Kehilangan air telaga yang begitu cepat dipengaruhi oleh (1) semakin sedikitnya imbuhan akibat semakin tipisnya tanah pada daerah tanngkapan air telaga sehingga air langsung masuk ke zona epikarst, (2) berkurangnya vegetasi di sekitar telaga yang menyebabkan penguapan menjadi sangat tinggi karena suhu meningkat dan kecepatan angin di atas telaga semakin tinggi, (3) pengerukan bagian bawah telaga yang menyebabkan kebocoran menuju ke sistem sungai bawah tanah. Permasalahan penurunan kualitas air pada telaga disebabkan oleh penggunaan bahan kimia dalam aktivitas mandi dan mencuci, serta pencemaran yang berasal dari kegiatan pertanian di daerah tangkapan air dari telaga.

\section{SIMPULAN}

Hasil penelitian menunjukkan bahwa telaga di kawasan karst Kecamatan Semanu Kabupaten Gunungkidul saat ini sudah tidak lagi digunakan sebagai sumber air minum. Namun demikian telaga masih digunakan untuk mencuci, memandikan ternak, menyirami tanaman, budidaya ikan air tawar dan sumber air bagi minum ternak. Hal ini berarti bahwa pasca pembangunan jaringan air bersih oleh PDAM telaga masih memberikan kontribusi yang besar bagi pemenuhan kebutuhan air di kawasan karst Kecamatan Semanu Kabupaten Gunungkidul, meskipun perannya sudah tidak sebesar masa lalu. 


\section{SARAN}

Pengelolaan telaga hendaknya tetap terus dilakukan dan diupayakan karena telaga di kawasan karst masih berperan besar dalam pemenuhan kebutuhan air penduduk. Namun demikian diperlukan suatu kajian tentang pengelolaan telaga yang berkelanjutan. Keluhan masyarakat terkait dengan kerusakan sejumlah telaga pasca pengelolaan secara teknik konvensional hendaknya memberikan suatu pembelajaran bagi pengelolaan telaga di masa mendatang. Selain itu, Pengelolaan wilayah tangkapan air dengan menetapkan sebagai kawasan berfungsi lindung dengan pembuatan mikro-zonasi tertentu patut diusahakan agar keberadaan telaga yang masih potensial dapat dijaga keberadaanya.

\section{UCAPAN TERIMA KASIH}

Terima kasih penulis sampaikan kepada Dr. Suyono, M.S., Hendy Fatchurohman, S.Si., dan Muhammad Azis Ramdhani, S.Si. atas diskusi menarik, saran, dan masukan selama penyusunan paper ini. Penulis juga menyampaikan terima kasih kepada pemerintah kecamatan dan desa di Kecamatan Semanu yang telah mengijinkan dan membantu pelaksanaan penelitian ini.

\section{DAFTAR PUSTAKA}

Balasz. 1968. Karst Region in Indonesia. Karszt-Es Barkangkutatas-Volume V. Budapest. Bappeda Kabupaten Gunungkidul. 2007. Penyusunan NeracaAir Kabupaten Gunungkidul,

Daerah Istimewa Yogyakarta. Laporan Penelitian. Wonosari: Bappeda Kabupaten Gunungkidul.

Cahyadi, A. 2010. Pengelolaan Kawasan Karst dan Peranannya dalam Siklus Karbon di Indonesia. Proseding Seminar Nasional Perubahan Iklim di Indonesia. Yogyakarta: Sekolah Pasca Sarjana UGM Yogyakarta.

Haryono E. dan Day, M. 2004. Landform Differentiation within The Gunung Kidul Kegelkarst, Java Indonesia. Journal of Cave and Karst Studies 66 (2): 62-68.

Haryono, E.; Adji, T.N. dan Widyastuti, M. 2009. Environmental Problems Of Telaga (Doline Pond) in Gununsewu Karst, Java Indonesia. dalam White, W.B. 2009. Proceeding 15th International Congress of Speleology, Volume II. Texas: UIS.

Marfai, M.A. Pengantar Pemodelan Geografi. Yogyakarta: Badan Penerbit Fakultas Geografi (BPFGE) Universitas Gadjah Mada.

Milanovic, P.T. 2004. Water Resources Engineering in Karst. Boca Raton, Florida: CRC Press. Rahadjo, W.; Rumidi, S. dan Rosidi, H.M.D.. 1995. Peta Geologi Lembar Yogyakarta, Jawa. Bandung: Pusat Penelitian dan Pengembangan Geologi, Badan Geologi.

Santosa, L.W. 2007. Kerusakan Telaga Dolin dan Faktor-Faktornya di Wilayah Perbukitan Karst Kabupaten Gunungkidul. Jurnal Kebencanaan Indonesia, 1(3): 176-193.

Surono; Toha, B. dan Sudarno J. (1992) Peta Geologi Lembar Surakarta-Giritontro, Jawa. Bandung Pusat Penelitian dan Pengembangan Geologi, Badan Geologi.

Suryono, T. 2006. Pengelolaan Sumber Air Bawah Tanah Sungai Bribin. Gunung Sewu Indonesian Cave and Karst Journal, 2(1): 37-52. 
Tjia, H.D. 2013. Morphostructural Development of Gunungsewu Karst, Jawa Island. Indonesian Journal of Geology, 8(2): 75-88.

White, W.B. 1988.Geomorphology and Hydrology of Karst Terrains. New York: Oxford University Press.

Worosuprojo, Suratrnan. 1997. Kajian Ekosistem Karst di Kabupaten Gunung Kidul Provinsi Daerah Istirnewa Yogyakarta. Laporan Penelitian. Yogyakarta: Fakultas Geografi UGM Yogyakarta dan Biro Bina Lingkungan Hidup Propinsi Daerah Istirnewa Yogyakarta. 